\title{
Time-resolved resonance Raman study of dioxygen reduction by cytochrome $c$ oxidase
}

\author{
Teizo Kitagawa and Takashi Ogura \\ Institute for Molecular Science, Okazaki National Research Institutes, Myodaiji, \\ Okazaki 444 Japan
}

\begin{abstract}
Six oxygen-associated vibrations were observed for reaction intermediates of bovine cytochrome $c$ oxidase with $\mathrm{O}_{2}$ using time-resolved resonance Raman spectroscopy at room temperature. The isotope frequency shifts for ${ }^{16} \mathrm{O}^{18} \mathrm{O}$, have established that the primary intermediate is an end-on type dioxygen adduct of $\mathrm{Fe}_{\mathrm{a} 3}$, which is followed by two oxoheme intermediates, and that the final intermediate appearing around $3 \mathrm{~ms}$ is the $\mathrm{Fe}-\mathrm{OH}$ heme. The reaction rate between the two oxoheme intermediates was significantly slower in $\mathrm{D}_{2} \mathrm{O}$ than in $\mathrm{H}_{2} \mathrm{O}$, suggesting tight coupling with proton translocation at this step. It is noted that the reaction intermediates of oxidized enzyme with hydrogen peroxide yields the same three sets of oxygen isotope-sensitive bands as those seen for oxoheme intermediates of the dioxygen reduction, indicating the identity of intermediates.
\end{abstract}

\section{INTRODUCTION}

The terminal oxidase of mitochondrial respiratory chain contains two copper redox centers $\left(\mathrm{Cu}_{\mathrm{A}}\right.$ and $\left.\mathrm{Cu}_{\mathrm{B}}\right)$ and two heme-A groups (Cyt $a$ and Cyt $a_{3}$ ) [1] and has been historically called cytochrome $a a_{3}$ (E.C. 1.9.3.1). A conceptual structure of this enzyme is illustrated in Fig. 1. The $\mathrm{Cu}_{\mathrm{A}}$ center, which is a binuclear complex and shuttles between $\mathrm{Cu}^{\prime} \mathrm{Cu}^{\mathrm{Il}}$ and $\mathrm{Cu}^{\prime} \mathrm{Cu}^{\mathrm{l}}$, receives electrons from cytochorme $c$ and gives them to Cyt $a$.. Heme $a$ is of a six-coordinate low-spin type and works simply for electron transfer from $\mathrm{Cu}_{\mathrm{A}}$ to $\mathrm{Cyt} a_{3}$, while heme $a_{3}$ is of a five-coordinate high-spin type and provides the catalytic site for $\mathrm{O}_{2}$ reduction. $\mathrm{Cu}_{B}$ is antiferromagnetically coupled with heme $a_{3}$ in the resting state and accordingly, is EPR silent, while the role of $\mathrm{Cu}_{\mathrm{B}}$ remains to be clarified. Full reduction of $\mathrm{O}_{2}$ to $\mathrm{H}_{2} \mathrm{O}$ needs four electrons and four protons. In a respiration system the reaction is catalyzed by the heme iron of Cyt $a_{3}\left(\mathrm{Fe}_{\mathrm{a}}\right)$ in stepwise, that is, repetitions of one electron transfer to oxygen followed by uptake of one proton [2]. In addition to four consumed protons for yielding two water molecules, another four protons are transported across the mitochondrial inner membrane to generate the electrochemical potential to be used for ATP synthesis from ADP $[3,4]$. The stepwise reduction of an isolated $\mathrm{O}_{2}$ molecule may imply generation of intermediately reduced oxygen species like $\cdot \mathrm{O}_{2}^{-}, \cdot \mathrm{OOH}, \mathrm{O}_{2}^{--}, \mathrm{OOH}^{-}, \mathrm{HOOH}, \mathrm{O}^{-}$, and $\cdot \mathrm{OH}$, which are called active oxygen and very toxic to organisms, but no such dangerous intermediates are normally released in the respiration process. Then, how is the molecular oxygen reduced in mitochondria and how is the electron trasfer coupled with the proton transport? The purpose of our study is to answer these questions.

Fig. 1. Concenptual illustration of cytochrome $c$ oxidase. The enzyme is located in the inner membrane of mitochondria and is functionally categorized into two parts, that is, cytochrome $a$ (Cyt a) and cytochrome $a_{3}\left(\right.$ Cyt $\left.\mathrm{a}_{3}\right)$. Cytocrome $c$ gives electrons to $\mathrm{Cu}_{\mathrm{A}}$, which actually consists of binuclear copper center. Electrons are transferred from $\mathrm{Cu}_{\mathrm{A}}$ to the six-coordinate heme (Cyt a) and then to the five-coordinate heme $\left(\mathrm{Cyt} \mathrm{a}_{3}\right) . \mathrm{Cu}_{\mathrm{B}}$ is anti-ferromagnetically coupled with the iron of Cyt $a_{3}$ in the resting state. $\mathrm{O}_{2}$ binds to the $\mathrm{Fe}^{\mathrm{II}}$ ion of Cyt $\mathrm{a}_{3}$ to which $\mathrm{CO}$ and $\mathrm{CN}^{-}$also can be bound. Upon reduction of one $\mathrm{O}_{2}$ molecule, four protons are translocated across the membrane from the matrix- to cytosol side and in addition, four protons are consumed in the matrix side to generate two water molecules.

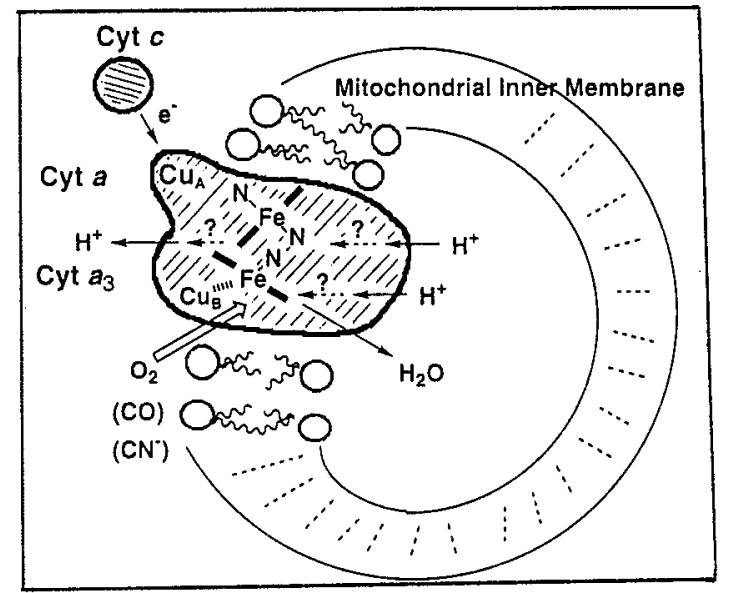


The three dimensional structure of bovine cytochorme $c$ oxidase $(\mathrm{CcO})$ with $\mathrm{M}_{\mathrm{r}}=2 \times 10^{5}$ and 13 subunits has been revealed recently with X-ray crystallography [5]. The reaction mechanism of this enzyme has been investigated with various spectroscopic techniques including time-resolved [6-8] and cryo-trapped absorption [9], and EPR [10,11] spectroscopy but more recently a breakthrough was made with time-resolved resonance Raman $\left(\mathrm{TR}^{3}\right)$ spectroscopy by Babcock' group [12,13], Rousseau' group [14,15] and our group [16-19]. The course of progress has been summarized in a comprehensive review article [20] and here, some hot results from our $\mathrm{TR}^{3}$ experiments [19] are explained.

\section{REACTION OF REDUCED CCO WITH $\mathrm{O}_{2}$}

\section{Time-Resolved Resonance Raman Spectra}

Resonance Raman (RR) spectroscopy allows to observe selectively the vibrational spectra of a chromophore by tuning the excitation wavelength into an absorption band of a molecule. Application of this technique to heme proteins has brought about unique and important information on dynamical as well as static structures [21]. In the time resolved measurements, the reaction was initiated by photolysis of $\mathrm{CO}$-inhibited $\mathrm{CcO}$ in the presence of $\mathrm{O}_{2}$ and after a certain delay time $\left(\Delta \mathrm{t}_{\mathrm{d}}\right) \mathrm{RR}$ spectra were determined. In this $\mathrm{TR}^{3}$ experiments, a device for simultaneous measurements of Raman and absorption spectra [22] and a sample circulation system for regenerating the reacted enzyme during one cycle [18] were constructed. Since the Raman intensities of the oxygen-associated vibrations are extremely weak, we measured the RR spectra of intermediates for ${ }^{16} \mathrm{O}_{2}$ and ${ }^{18} \mathrm{O}$, at the same time under an identical condition and calculated their differences.

Figure 2 shows the $\mathrm{TR}^{3}$ spectra observed with the delay times of 0.1 (A), 0.27 (B), 0.54 (C), 2.7 (D) and $5.4 \mathrm{~ms}$ (E) for the $\mathrm{H}_{2} \mathrm{O}$ solution at $3{ }^{\circ} \mathrm{C}$ [19]. The visible absorption spectrum simultaneously observed with spectrum (A) is close to that of Compound A obtained in cryogenic techniques[9]. Spectrum (A) shows the Fe- $\mathrm{O}_{2}$ stretching $\left(v_{\mathrm{Fe}-\mathrm{O} 2}\right) \mathrm{RR}$ bands at $571 / 544 \mathrm{~cm}^{-1}$ for the ${ }^{16} \mathrm{O}_{2} /{ }^{18} \mathrm{O}_{2}$ derivatives. The frequencies and isotope shift are very close to those seen for $\mathrm{HbO}_{2}$ and $\mathrm{MbO}_{2}$ [23]. In the next stage $\left(\Delta \mathrm{t}_{\mathrm{d}}=0.27 \mathrm{~ms}\right)$, new Raman bands appear at $804 / 764,785 / 750$, and $356 / 342 \mathrm{~cm}^{-1}$. Spectrum (D) which exibits only the $785 / 750 \mathrm{~cm}^{-1}$ pair

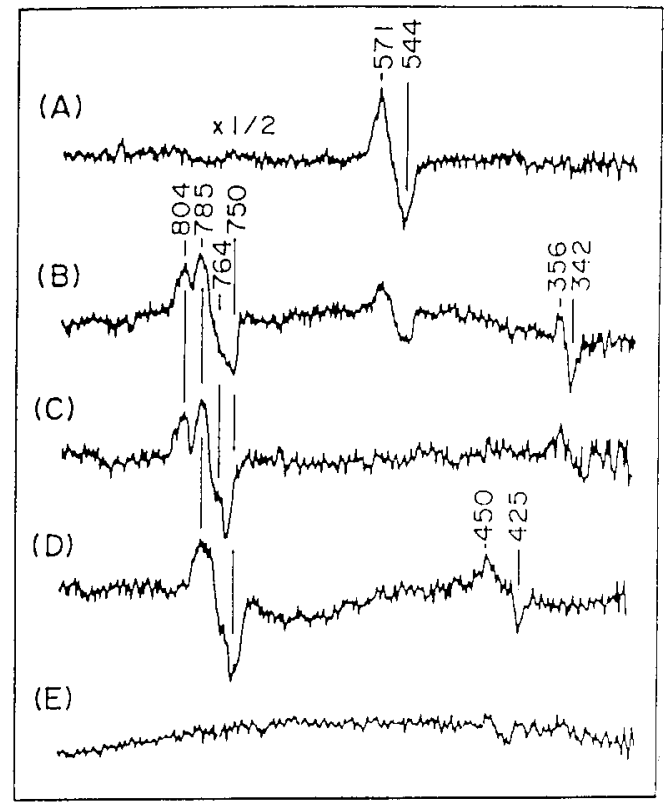

RAMAN SHIF T/ $\mathrm{cm}^{-1}$

Fig. 2. $\mathrm{TR}^{3}$ difference spectra of reaction intermediates of $\mathrm{CcO}$ in $\mathrm{H}_{2} \mathrm{O}$. The Raman difference spectra obtained by subtracting the spectrum of the corresponding ${ }^{18} \mathrm{O}_{2}$ derivative from the spectrum of ${ }^{16} \mathrm{O}_{2}$ derivative at each delay time are depicted. Therefore, positive and negative peaks denote the contributions of ${ }^{16} \mathrm{O}_{2}$ and ${ }^{18} \mathrm{O}_{2}$-derivatives, respectively. Delay time after initiation of the reaction is $0.1(\mathrm{~A}), 0.27$ (B), 0.54 (C), 2.7 (D) and $5.4 \mathrm{~ms}$ (E). Excitation wavelength, $423 \mathrm{~nm}$; Temperature, 3 ${ }^{\circ} \mathrm{C}$. (Taken from Ref. 19).

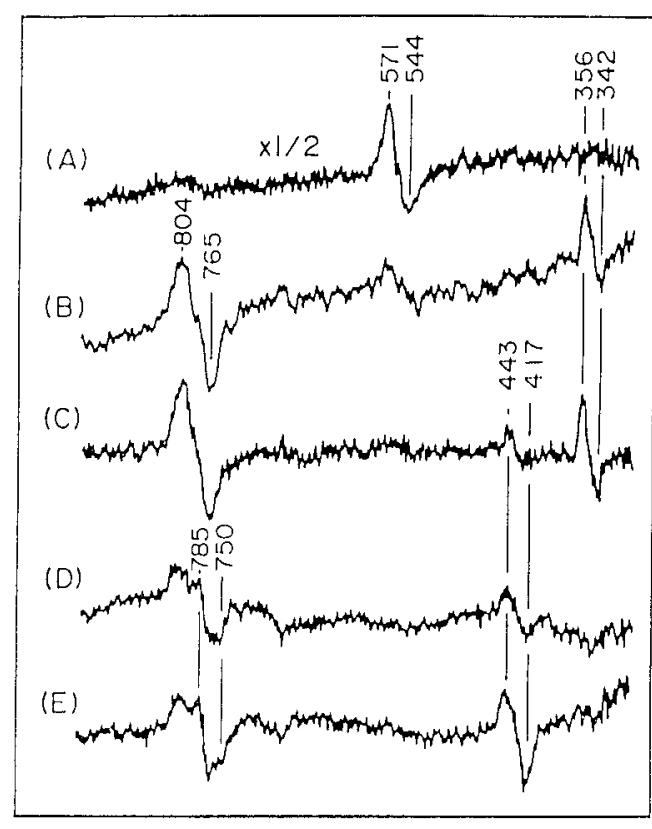

RAMAN SHIF T/ $\mathrm{cm}^{-1}$

Fig. 3. $\mathrm{TR}^{3}$ difference spectra of reaction intermediates of $\mathrm{CcO}$ in $\mathrm{D}_{2} \mathrm{O}$. Delay time is 0.1 (A), 0.54 (B), 2.7 (C), 6.5 (D) and 11 $\mathrm{ms}(\mathrm{E})$. Other conditions are the same as those for Fig. 2. (Taken from Ref. 19). 
near $800 \mathrm{~cm}^{-1}$ strongly suggests that the $804 / 764 \mathrm{~cm}^{-1}$ pair precedes the $785 / 750 \mathrm{~cm}^{-1}$ pair. The $450 / 425 \mathrm{~cm}^{-1}$ pair, which arises from the $\mathrm{Fe}-\mathrm{OH}$ stretch $\left(v_{\mathrm{Fe}-\mathrm{OH}}\right)$ of the $\mathrm{Fe}_{a 3}{ }^{11 \mathrm{II}}-\mathrm{OH}$ heme $[13,15,17]$, appears at $\Delta \mathrm{t}_{\mathrm{d}}=2.7 \mathrm{~ms}$, but disappears at $\Delta \mathrm{t}_{\mathrm{d}}=5.4 \mathrm{~ms}$ due to exchanges of the bound ${ }^{18} \mathrm{OH}^{-}$anion with bulk water. This $\mathrm{v}_{\mathrm{Fe}-\mathrm{OH}}$ frequency is significantly lower than those of aquametHb and aquametMb at $495 \mathrm{ad} 490 \mathrm{~cm}^{-1}$, respectively [24], presumably due to strong interaction between the bound $\mathrm{OH}^{-}$group and $\mathrm{Cu}_{\mathrm{B}}$.

Figure 3 shows similar difference $R R$ spectra observed with $\Delta \mathrm{t}_{\mathrm{d}}=0.1$ (A), 0.54 (B), 2.7 (C), 6.5 (D) and 11 $\mathrm{ms}$ (E) for the $\mathrm{D}_{2} \mathrm{O}$ solution at $3{ }^{\circ} \mathrm{C}$. The $\mathrm{v}_{\mathrm{Fe}-02}$ frequencies in spectrum (A) are the same as those in Fig. 2(A). With the delay times of $\Delta \mathrm{t}_{\mathrm{d}}=0.54$ (B) and $2.7 \mathrm{~ms}(\mathrm{C})$, however, a single differential band was observed around $800 \mathrm{~cm}^{-1}$ (at $804 / 764 \mathrm{~cm}^{-1}$ ), contrary to the case for the $\mathrm{H}_{2} \mathrm{O}$ solution. Therefore, it was misunderstood once [18] that the $785 / 750 \mathrm{~cm}^{-1}$ bands in the $\mathrm{H}_{2} \mathrm{O}$ solution were shifted to $796 / 766 \mathrm{~cm}^{-1}$ in $\mathrm{D}_{2} \mathrm{O}$, giving rise to an overlapping band centered around $800 \mathrm{~cm}^{-1}$. However, it turned out from Fig. 3 that the lifetime of the $804 / 764 \mathrm{~cm}^{-1}$ species is so different between the $\mathrm{H}_{2} \mathrm{O}$ and $\mathrm{D}_{2} \mathrm{O}$ solutions that the $785 / 750$ $\mathrm{cm}^{-1}$ species was not generated in $\mathrm{D}_{2} \mathrm{O}$ yet at $\Delta \mathrm{t}_{\mathrm{d}}=2.7 \mathrm{~ms}$. It is noted that the $356 / 342 \mathrm{~cm}^{-1}$ bands are clearly seen in spectra (B) and (C) at the same frequencies as those in the $\mathrm{H}_{2} \mathrm{O}$ solution. Spectra (D) and (E) for the $\mathrm{D}_{2} \mathrm{O}$ solution demonstrated that the $785 / 750 \mathrm{~cm}^{-1}$ bands did appear at the same frequencies but much later than those in the $\mathrm{H}_{2} \mathrm{O}$ solution. It is estimated that the conversion rate from the $804 / 764 \mathrm{~cm}^{-1}$ species to the $785 / 750 \mathrm{~cm}^{-1}$ species in $\mathrm{D}_{2} \mathrm{O}$ is approximately one fifth of that in $\mathrm{H}_{2} \mathrm{O}$. The subsequent appearance of the $443 / 417 \mathrm{~cm}^{-1}$ bands, which arise from the Fe-OD stretch, is consistent with the results shown in Fig. 2. The experiments with $\Delta \mathrm{t}_{\mathrm{d}}=0.3 \sim 0.5 \mathrm{~ms}$ for $\mathrm{D}_{2} \mathrm{O}$ solutions (data not shown) yielded the $804 / 764$ and $356 / 342 \mathrm{~cm}^{-1}$ bands in a manner similar to spectrum (B).

When the mixed valence CO-bound enzyme, which had only two electrons in a molecule, was used as a starting compound instead of the fully reduced $\mathrm{CO}$-bound enzyme, which had four electrons, the primary intermediate gave the $\mathrm{O}_{2}$-isotope-sensitive bands at $571 / 544 \mathrm{~cm}^{-1}[25,26]$. The subsequent intermediate, which is characterized by the difference absorption peak at $607 \mathrm{~nm}$ (intermediates - fully oxidized), was found to give RR bands at $804 / 764$ and $356 / 342 \mathrm{~cm}^{-1}$ for ${ }^{16} \mathrm{O}_{2}{ }^{18} \mathrm{O}_{2}$ [19]. These bands lasted as long as $\Delta \mathrm{t}_{\mathrm{d}}=4.2 \mathrm{~ms}$ but the bands at $785 / 750$ and $450 / 425 \mathrm{~cm}^{-1}$ did not appear in this case. These results have proved that the species giving rise to the $804 / 764 \mathrm{~cm}^{-1}$ pair has an oxidation state higher than that of the $785 / 750 \mathrm{~cm}^{-1}$ species. Hirota et al. [27] carried out similar $\mathrm{TR}^{3}$ experiments for the reaction intermediates of fully reduced $E$. coli cytochrome $b o$ with $\mathrm{O}_{2}$, and found the $\mathrm{O}_{2}$-isotopesensitive bands at $568 / 535,788 / 751$, and $361 / 347 \mathrm{~cm}^{-1}$ but not those corresponding to the bands of cytochrome $a a_{3}$ at $804 / 764 \mathrm{~cm}^{-1}$, presumably owing to very short lifetime.

\section{Binding Geometry of $\mathrm{O}_{2}$}

In order to determine whether the dioxygen adduct of $\mathrm{CcO}$ adopts the side-on or end-on geometry, Ogura et al. [18] examined RR spectra of ${ }^{16} \mathrm{O}^{18} \mathrm{O}$-bound $\mathrm{CcO}$. The results

Fig. 4. $\mathrm{TR}^{3}$ difference spectra in the $\mathrm{Fe}^{\mathrm{III}}-\mathrm{O}_{2}^{-}$ stretching region of $\mathrm{CcO}$ at the delay time of $0.1 \mathrm{~ms}$. left side: observed spectra; right side: calculated spectra; (A) ${ }^{16} \mathrm{O}_{2}-{ }^{18} \mathrm{O}_{2}$; (B) ${ }^{16} \mathrm{O}^{18} \mathrm{O}-{ }^{18} \mathrm{O}_{2}$; (C) ${ }^{16} \mathrm{O}_{2}$ ${ }^{16} \mathrm{O}^{18} \mathrm{O}$; (D) ${ }^{16} \mathrm{O}^{28} \mathrm{O}-\left({ }^{2} \mathrm{O}_{2}+{ }^{18} \mathrm{O}_{2}\right) / 2$. (E) The Fe${ }^{16} \mathrm{O}_{2}(1), \mathrm{Fe}-{ }^{16} \mathrm{O}^{18} \mathrm{O}(2), \mathrm{Fe}^{18} \mathrm{O}^{16} \mathrm{O}(3)$, and $\mathrm{Fe}-{ }^{18} \mathrm{O}_{2}$ (4) stretching Raman bands assumed for the simulation. Their peak intensity ratios are 6:6:5:5, and all have a Gaussian band shape with a FWHM of 12.9 $\mathrm{cm}^{-1}$. In the calculation for the ${ }^{16} \mathrm{O}^{18} \mathrm{O}$ spectrum, (spectrum $2+$ spectrum 3)/2 was used. The differences between the observed and calculated spectra are depicted with the same ordinate scale as that of the observed spectra under the individual calculated spectra. experimental conditions: probe beam, $423 \mathrm{~nm}, 4 \mathrm{~mW}$; pump beam, $590 \mathrm{~nm}, 210$ $\mathrm{mW}$; accumulation time, $4800 \mathrm{~s}$. (Taken from Ref. $18)$.

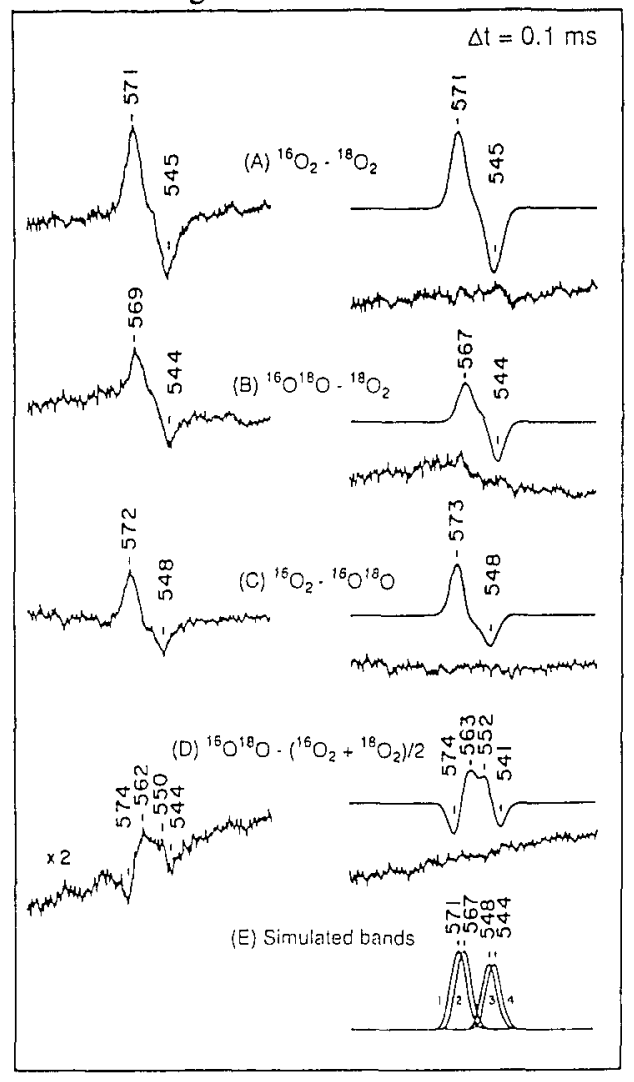

RAMAN SHIFT/ $\mathrm{cm}^{-1}$ 
are shown in Fig. 4, where the observed and simulated isotope-difference spectra are depicted on the left and right sides, respectively, and the combination of the isotope species in the difference calculations is specified in the middle. If ${ }^{16} \mathrm{O}^{18} \mathrm{O}$ binds to $\mathrm{Fe}_{\mathrm{a} 3}{ }^{11}$ in an end-on geometry, the $\mathrm{v}_{\mathrm{Fe}-\mathrm{O} 2}$ frequencies for $\mathrm{Fe}-{ }^{16} \mathrm{O}-{ }^{18} \mathrm{O}$ and $\mathrm{Fe}$ ${ }^{18} \mathrm{O}-{ }^{16} \mathrm{O}$ should be different. Since these two species will be generated by equal amounts, two $v_{\mathrm{Fe}-\mathrm{O} 2} \mathrm{RR}$ bands should appear. On the other hand, if the binding is of an side-on type, the $v_{\mathrm{Fe}-02}$ frequencies for $\mathrm{Fe}\left({ }^{16} \mathrm{O}^{18} \mathrm{O}\right)$ and $\mathrm{Fe}\left({ }^{18} \mathrm{O}^{16} \mathrm{O}\right)$ are identical and are located in the middle of the $v_{\mathrm{Pe}-\mathrm{O} 2}$ frequencies of the ${ }^{16} \mathrm{O}_{2}$ - and ${ }^{18} \mathrm{O}_{2}$-adducts.

The difference-peak intensities in spectra (B) and (C) are weaker than those in spectrum (A) and peak frequencies are slightly different. If it is assumed that the ${ }^{16} \mathrm{O}_{2}$ and ${ }^{18} \mathrm{O}_{2}$ species give a single $v_{\mathrm{Fe}-02}$ RR band at 571 and $544 \mathrm{~cm}^{-1}$, respectively, but the ${ }^{16} \mathrm{O}^{18} \mathrm{O}$ species gives two $v_{\mathrm{Fe}-\mathrm{O} 2}$ bands at 567 and $548 \mathrm{~cm}^{-1}$ with Gaussian band shapes $\left(\Delta v_{1 / 2}=12.9 \mathrm{~cm}^{-1}\right)$ and intensities as representedby spectra $(E)$, the difference calculations for the combinations specified for (A) through (D) yielded the patterns as delineated on the right side. The residuals in the subtraction of the simulated spectrum from the observed spectrum are depicted below each simulated spectrum. The calculated difference spectrum, ${ }^{16} \mathrm{O}^{18} \mathrm{O}-\left({ }^{16} \mathrm{O}_{2}+{ }^{18} \mathrm{O}_{2}\right) / 2$ (spectrum D), gives positive peaks at 563 and $552 \mathrm{~cm}^{-1}$ and troughs at 574 and $541 \mathrm{~cm}^{-1}$, which are in good agreement with the observed spectra. This suggests that the $\mathrm{Fe}-\mathrm{O}_{2}$ stretching frequencies for the $\mathrm{Fe}-{ }^{16} \mathrm{O}-{ }^{18} \mathrm{O}$ and $\mathrm{Fe}-{ }^{18} \mathrm{O}-{ }^{16} \mathrm{O}$ species are 567 and $548 \mathrm{~cm}^{-1}$, respectively. The magnitude of the isotopic frequency shifts and the simple normal coordinate calculations allowed us to estimate the Fe-O-O bond angle to be nearly $120^{\circ}$ similar to that in $\mathrm{HbO}_{2}$ and $\mathrm{MbO}_{2}$. Thus, this experiment established that the binding of $\mathrm{O}_{2}$ to $\mathrm{Fe}_{43}$ in $\mathrm{CcO} \cdot \mathrm{O}_{2}$ is of the endon type.

\section{Assignments of Transient RR Bands Around $800 \mathrm{~cm}^{-1}$}

Spectra (B) and (C) in Fig. 2 at $\Delta \mathrm{t}_{\mathrm{d}}=0.27$ and $0.54 \mathrm{~ms}$ give two oxygen-isotope sensitive bands around 800 $\mathrm{cm}^{-1}$, and the higher frequency component arises from the species with the $\mathrm{Fe}^{\mathrm{v}}$ oxidation level (compound I of peroxidase). In this frequency region, two kinds of oxygen-associated bands are expected; one is the peroxy $\mathrm{O}^{-}-\mathrm{O}^{-}$stretch $\left(v_{\mathrm{OO}}\right)$ and the other is an ironoxo $\mathrm{Fe}=\mathrm{O}$ stretch $\left(\mathrm{V}_{\mathrm{Fe}=\mathrm{O}}\right)$. These two modes cannot be distinguished by the ${ }^{16} \mathrm{O}_{2}$ and ${ }^{18} \mathrm{O}_{2}$ isotopic frequency shifts. However, if ${ }^{16} \mathrm{O}^{18} \mathrm{O}$ is used to produce such intermediates, the distinction would be possible. The peroxy intermediate for ${ }^{16} \mathrm{O}^{18} \mathrm{O}$ is expected to give an additional $v_{\text {oo }}$ band in a middle of those for the ${ }^{16} \mathrm{O}_{2}$ and ${ }^{18} \mathrm{O}_{2}$ derivatives. In contrast, the oxo intermediate for ${ }^{16} \mathrm{O}^{18} \mathrm{O}$ is expected to yield two bands at the same frequencies as those seen for the ${ }^{16} \mathrm{O}_{2}$ and ${ }^{18} \mathrm{O}_{2}$ derivatives but with half intensity.

Such a distinction was satisfactorily carried out with ${ }^{16} \mathrm{O}^{18} \mathrm{O}$ on the $804 / 764$ and $785 / 750 \mathrm{~cm}^{-1}$ bands. The results are shown in Fig. 5, where the $\mathrm{TR}^{3}$ difference spectra observed with $\Delta \mathrm{t}_{\mathrm{d}}=1.1 \mathrm{~ms}$ at $5{ }^{\circ} \mathrm{C}$ for the $\mathrm{H}_{2} \mathrm{O}$ and $\mathrm{D}_{2} \mathrm{O}$ solutions are presented on the left and right sides, respectively. The various isotope combinations

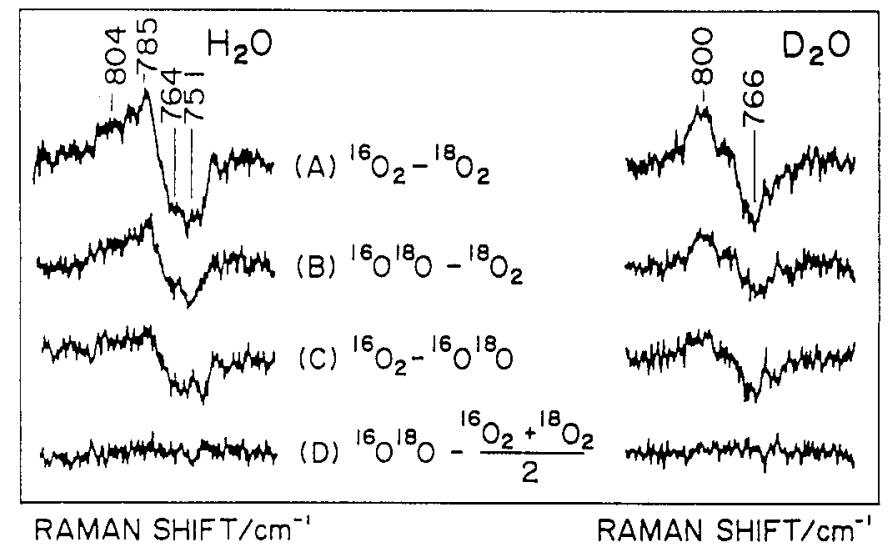

Fig. 5. Higher resolution $\mathrm{TR}^{3}$ difference spectra of $\mathrm{CcO}$ reaction intermediates in the $\sim 800 \mathrm{~cm}^{-1}$ region for the delay time of $1.1 \mathrm{~ms}$ at $5{ }^{\circ} \mathrm{C}$ for $\mathrm{H}_{2} \mathrm{O}$ (left) and $\mathrm{D}_{2} \mathrm{O}$ solutions (right). The ordinate scales are common to all spectra. The spectra combined in the difference calculations are specified in the middle of the figure. Resolution, $0.43 \mathrm{~cm}^{-1} /$ channel. (Taken from Ref. 18). 
are defined in the center of the figure. In trace (A) for the $\mathrm{H}_{2} \mathrm{O}$ solution, there are two bands at 804 and 785 $\mathrm{cm}^{-1}$ for ${ }^{16} \mathrm{O}_{2}$ and they are downshifted to 764 and $751 \mathrm{~cm}^{-1}$ with ${ }^{18} \mathrm{O}_{2}$, in agreement with Fig. 2(B), obtained in independent experiments with different batches of the enzyme preparations. It is evident that the peak positions and spectral patterns of the difference spectra (B) and (C) in Fig. 5 for the $\mathrm{H}_{2} \mathrm{O}$ solution are alike and similar to those of spectrum (A) but their intensities are approximately half of those in spectrum (A). The same features are also seen for the $\mathrm{D}_{2} \mathrm{O}$ solution (right side). The point to be emphasized is that there is no difference peak in the bottom traces for either the $\mathrm{H}_{2} \mathrm{O}$ or $\mathrm{D}_{2} \mathrm{O}$ solution. This feature definitely differs from that seen in Fig. 4(D).

These results indicate that only one atom of $\mathrm{O}_{2}$ is primarily responsible for the two RR bands. In other words, neither of the bands at $804 / 764$ nor $785 / 750 \mathrm{~cm}^{-1}$ are assignable to the $\mathrm{O}-\mathrm{O}$ stretching mode. Although the two sets of $\mathrm{RR}$ bands arise from an $\mathrm{Fe}=\mathrm{O}$ stretch, electronic properties of their hemes seem to be distinct, because the $804 / 764 \mathrm{~cm}^{-1}$ bands, but not the $785 / 750 \mathrm{~cm}^{-1}$ bands, were clearly identified upon Raman excitation at 607 and $441.6 \mathrm{~nm}$, but only the $785 / 750 \mathrm{~cm}^{-1}$ bands were observed upon excitation at $567.1 \mathrm{~nm}$.

\section{Assignment of the Transient Band Around $350 \mathrm{~cm}^{-1}$}

Relative intensities of the $804 / 764$ and $356 / 342 \mathrm{~cm}^{-1}$ bands are altered with the delay time and, upon excitation at $441.6 \mathrm{~nm}$, the $356 / 342 \mathrm{~cm}^{-1}$ bands are not enhanced while the $804 / 764 \mathrm{~cm}^{-1}$ bands are clearly observed. Therefore, the two sets of bands are considered to arise from separate molecular species. To clarify the assignment of this band, Ogura et al. [18] examined the ${ }^{16} \mathrm{O}^{18} \mathrm{O}$ effect on the $356 / 342 \mathrm{~cm}^{-1}$ bands. The results are shown in Fig. 6, where spectra (A-D) were obtained for the indicated (in the figure) combinations of $\mathrm{O}_{2}$-isotopes in the $\mathrm{H}_{2} \mathrm{O}$ solution and spectrum (E) was obtained for combination (A) in the $\mathrm{D}_{2} \mathrm{O}$ solution. Spectra in Figs. 5 are 6 are represented on the same wavenumber scale. It is noticed that the $356 \mathrm{~cm}^{-1}$ band is very narrow. The inset of Fig. 6 (spectra $A^{\prime}$ and $E^{\prime}$ ) shows redrawing of spectra (A) and (E) with the wavenumber axis expanded by 2.5 fold. The $356 \mathrm{~cm}^{-1}$ band appears to be somewhat broader in $\mathrm{D}_{2} \mathrm{O}$ than in $\mathrm{H}_{2} \mathrm{O}$, but both spectra exhibit a flat region between the positive and negative peaks. This means that the separation between the ${ }^{16} \mathrm{O}_{2}$ and ${ }^{18} \mathrm{O}_{2}$ peaks is larger than their bandwidths, and thus the narrowness of the band is not the consequence of the close proximity of the ${ }^{16} \mathrm{O}_{2}$ and ${ }^{18} \mathrm{O}_{2}$ bands. This also means that the peak positions of the difference spectrum correctly represent those of each spectrum.

It is evident from spectrum (E) that there are no deuteration effects on the absolute frequencies of the $356 / 342$ $\mathrm{cm}^{-1}$ bands. Therefore, this band cannot be a $\mathrm{Cu}-\mathrm{OH}$ stretching mode. As was seen for the bands around $800 \mathrm{~cm}^{-1}$, spectra (B) and (C) do not differ from each other in shape or position of the peaks, which are also close to those of spectrum (A). If the $356 / 342 \mathrm{~cm}^{-1}$ bands arose from the Fe-OOH stretch, the frequency difference between the $\mathrm{Fe}-{ }^{16} \mathrm{O}^{18} \mathrm{OH}$ and $\mathrm{Fe}-{ }^{16} \mathrm{O}^{16} \mathrm{OH}$ streches and that between the $\mathrm{Fe}-{ }^{18} \mathrm{O}^{16} \mathrm{OH}$ and $\mathrm{Fe}$ ${ }^{18} \mathrm{O}^{18} \mathrm{OH}$ stretches should be as large as $2.5 \mathrm{~cm}^{-1}$ unless the $\mathrm{Fe}-\mathrm{O}-\mathrm{O}$ bond-angle is close to $90^{\circ}$, and there should be some difference peaks in Fig. 6(D) as seen for the Fe-O adduct in Fig. 4(D). Actually, however, there is no difference peak in spectrum (D) in Fig. 6. Therefore, only one oxygen atom from the $\mathrm{O}_{2}$ molecule is primarily responsible for the $356 \mathrm{~cm}^{-1}$ band, too.

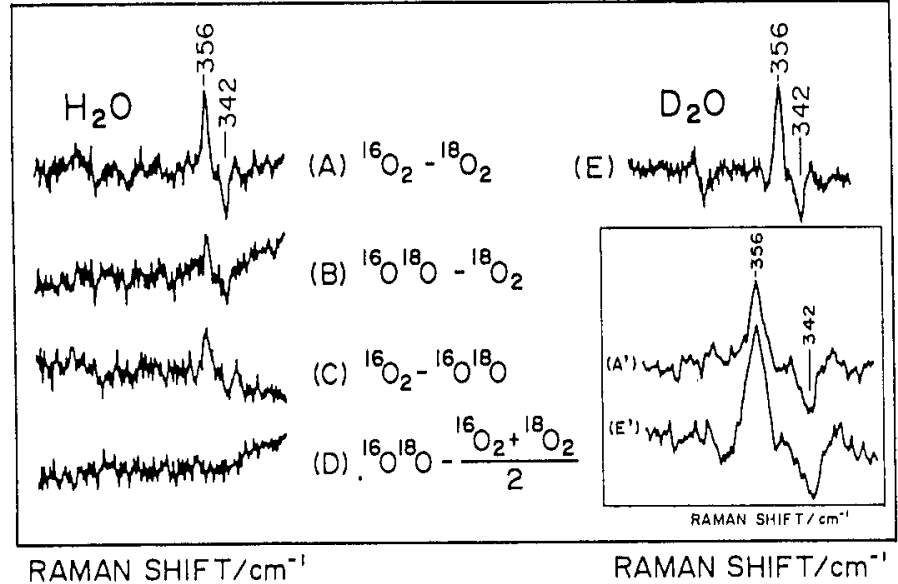

Fig. 6. $\mathrm{TR}^{3}$ difference spectra of $\mathrm{CcO}$ reaction intermediates in the $\sim 350$ $\mathrm{cm}^{-1}$ region for $\Delta \mathrm{t}_{\mathrm{d}}=0.5 \mathrm{~ms}$ at $5{ }^{\circ} \mathrm{C}$ for $\mathrm{H}_{2} \mathrm{O}$ (left) and $\mathrm{D}_{2} \mathrm{O}$ solutions (right). The ordinate scales are common to all spectra. The spectra combined in the difference calculations are specified in the middle of the figure. The inset depicts the plots of spectra $A$ and $E$ expanded by a factor of 2.5 in the wavenumber axis. (Taken from Ref. 18). 


\section{REACTION OF OXIDIZED CcO WITH $\mathrm{H}_{2} \mathrm{O}_{2}$}

The reaction of ferric heme proteins with $\mathrm{H}_{2} \mathrm{O}_{2}$ usually yields the $\mathrm{Fe}^{\mathrm{v}}$-level intermediate first, which is then successively reduced to the $\mathrm{Fe}^{\mathrm{IV}}$ and $\mathrm{Fe}^{\mathrm{Ill}}$ oxidation levels. The reaction of oxidized $\mathrm{CcO}$ with $\mathrm{H}_{2} \mathrm{O}_{2}$ has been extensively studied with visible absorption [28], EPR [29] and RR [30-32]. The visible absorption spectra of reaction intermediates are displayed in Fig. 7, where the differences between the intermediates and fully oxidized enzyme for several delay times are depicted [31]. The so-called "607 nm" form is generated first and then it is replaced by the "580 $\mathrm{nm}$ " form. This feature is more clearly seen in the inset, where the difference absorbances at 607 and $578 \mathrm{~nm}$ with regard to those of the fully oxidized form are plotted against time. The rate of formation of the "607 $\mathrm{nm}$ " form was found to be proportional to the concentration of $\mathrm{H}_{2} \mathrm{O}_{2}$ and was considered to be the primary intermediate in this reation. This fact means that the "607 nm" form has the $\mathrm{Fe}^{\mathrm{V}}$ oxidation level of the heme $a_{3}$. When the concentration of $\mathrm{H}_{2} \mathrm{O}_{2}$ is increased, the "580 $\mathrm{nm}$ " form is developed rapidly. This is interpreted in the following way. Under high concentrations $\mathrm{of}_{2} \mathrm{O}_{2}$, the "607 $\mathrm{nm}$ " form developes much faster and the extra $\mathrm{H}_{2} \mathrm{O}_{2}$ acts as a reductant to the "607 nm" form to yield the "580 $\mathrm{nm}$ " form, which has the $\mathrm{Fe}^{\mathrm{IV}}$ oxidation level of the heme $a_{3}$ Accordingly, relative populations of the "607 nm" and "580 nm" forms can be regulated by the concentration of $\mathrm{H}_{2} \mathrm{O}_{2}$ and $\mathrm{pH}$ [32].

Figure 8 shows the absorption (right) and Soret-excited RR spectra (left) of intermediates which were measured simultaneously with an improved Raman/absorption simultaneous measurement device [30]. In this experiment the concentrations of reaction intermediates in question are retained in a steady state for a certain period of time by adding $\mathrm{H}_{2} \mathrm{O}_{2}$ at a constant rate to the circulating solution. The upper spectra were obtained under the conditions where the "607 nm" form is dominant, while the lower spectra were obtained under the conditions where the "580 nm" form is dominant. Both RR spectra are represented as the difference between the derivatives obtained from $\mathrm{H}_{2}{ }^{16} \mathrm{O}_{2}$ and $\mathrm{H}_{2}{ }^{18} \mathrm{O}_{2}$, and accordingly positive and negative peaks correspond to the vibrations associated with ${ }^{16} \mathrm{O}$ and ${ }^{18} \mathrm{O}$, respectively. It is noted that when the "607 $\mathrm{nm}^{\prime}$ form is dominant, the $804 / 769 \mathrm{~cm}^{-1}$ bands are clearly observed and when the "580 nm" form is dominant, broad bands centered around $785 / 750 \mathrm{~cm}^{-1}$ and sharp bands at $355 / 340 \mathrm{~cm}^{-1}$ are intensified. The intensity of the $355 / 340 \mathrm{~cm}^{-1}$ bands relative to those of the $804 / 769$ and $785 / 750 \mathrm{~cm}^{-1}$ bands were varied with each experiment. This strongly suggested that the species giving rise to the $355 / 340 \mathrm{~cm}^{-1}$ bands also gives a difference band around $800 / 760 \mathrm{~cm}^{-1}$ but is different from the two species giving rise to the $804 / 769$ and $785 / 750 \mathrm{~cm}^{-1}$ bands. The $355 / 340 \mathrm{~cm}^{-1}$ species seems to have an absorption spectrum similar to that of the "580 nm" form. This implies that the "580 nm" form consists of multiple intermediate species [32]. It is stressed that all these oxygen isotope-sensitive bands are identical with those observed in the dioxygen reduction.

Hitherto the "607 nm" form has been believed to be a peroxo species, namely, Fe-O-O-X (X= $\mathrm{H}$ or $\left.\mathrm{Cu}_{\mathrm{B}}\right)$. Since both the $\mathrm{O}^{-}-\mathrm{O}^{-}$and $\mathrm{Fe}=\mathrm{O}$ stretching frequencies are located around $800 \mathrm{~cm}^{-1}$, it is impossible to determine which type of vibrations was observed for the "607 nm" form in Fig. 8. In order to sort out between the two possible modes, experiments using $\mathrm{H}_{2}^{16} \mathrm{O}^{18} \mathrm{O}$ have been performed. The results are shown in Fig. 9, where RR spectra of the "607 $\mathrm{nm}$ " form excited at $607 \mathrm{~nm}$ are displayed for intermediates derived with $\mathrm{H}_{2}{ }^{16} \mathrm{O}_{2}$ (A), $\mathrm{H}_{2}^{18} \mathrm{O}_{2}$ (B), and $\mathrm{H}_{2}{ }^{16} \mathrm{O}^{18} \mathrm{O}$ (C) [31]. The band of the $\mathrm{H}_{2}{ }^{16} \mathrm{O}_{2}$ derivative at $803 \mathrm{~cm}^{-1}$ (A) is shifted to $769 \mathrm{~cm}^{-1}$ for the $\mathrm{H}_{2}{ }^{28} \mathrm{O}_{2}$ derivative (B), while other bands arising from the porphyrin macrocycle remain unshifted. This is most clearly seen in the difference spectrum (D) (= spectrum (A) spectrum (B)). The inset shows the same difference spectrum in a wider spectral range $\left(930-550 \mathrm{~cm}^{-1}\right)$. It is evident that there is no other oxygen associated band in this frequency region.

In spectrum (C) for the $\mathrm{H}_{2}{ }^{16} \mathrm{O}^{18} \mathrm{O}$ derivative, there are two bands at 803 and $769 \mathrm{~cm}^{-1}$, and their intensities relative to the

Fig. 7. Transient absorption spectra for reaction intermediates of oxidized $\mathrm{CcO}$ with $\mathrm{H}_{2} \mathrm{O}_{2}$. The spectra are represented as difference spectra with regard to the spectrum of fully oxidized enzyme and delay times after initiation of the reaction are specified at the right side of each spectrum. The zero line for each spectrum is shifted for clear presentation. Inset depicts the behavior of absorbances at 607 and $578 \mathrm{~nm}$ against delay times. (Full scale of $\Delta \mathrm{A}$ is 0.04 in terms of the difference, intermediate minus fully oxidized). (Taken from Ref. 31 ).

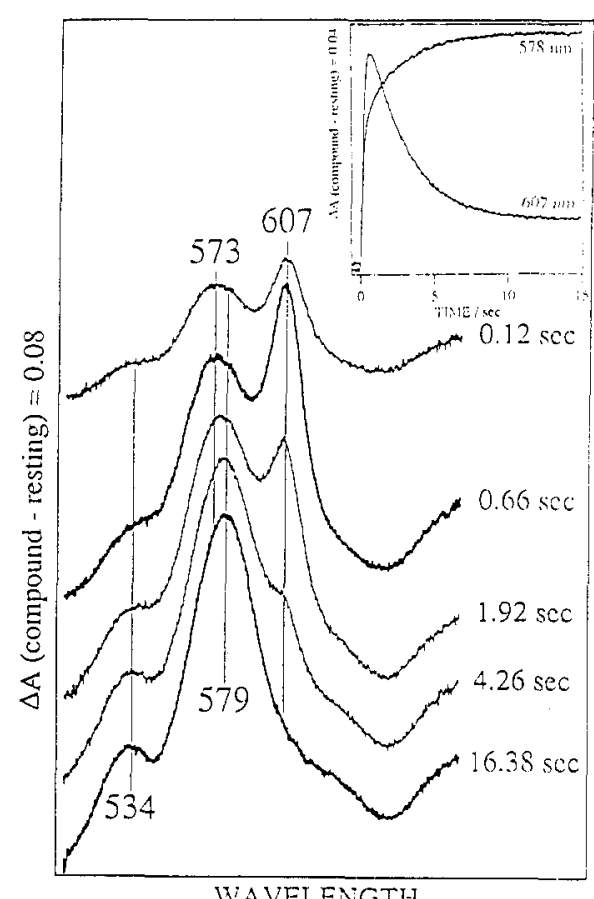

WAVELENGTH 
porphyrin bands are reduced to half of those in spectra (A) and (B). This is most clearly seen by the difference spectrum (E) $[=\operatorname{spectrum~(C)~-~}$ (spectrum (A) + spectrum (B))/2], which exhibits no band in the 700 $900 \mathrm{~cm}^{-1}$ region. This means that the $803 / 769 \mathrm{~cm}^{-1}$ bands arise from a species which has a single oxygen atom on the heme iron. Consequently, the peroxide structure (Fe-O-O-X), postulated for the "607 $\mathrm{nm}$ " form, was proved to be no longer valid.

\section{CONCLUSION}

The reaction intermediates of $\mathrm{CcO}$ characterized by RR spectroscopy and other spectroscopic techniques are inter-related in Fig. 10, where the oxygen-associated frequencies for ${ }^{16} \mathrm{O} /{ }^{88} \mathrm{O}$ are also specified. Two kinds of reactions, that is, dioxygen cycle (right) and peroxide cycle (left) were treated in this article. The first intermediate in the reaction of reduced $\mathrm{CcO}$ with $\mathrm{O}_{2}$, which has been called Compound $\mathrm{A}$ has now been demonstrated to be a dioxygen adduct of cytochrome $a_{3}$ with $\mathrm{v}_{\mathrm{Fe}-\mathrm{O} 2}$ at $571 \mathrm{~cm}^{-1}$. The binding of $\mathrm{O}_{2}$ is of an end-on type. The subsequent intermediates, called Compound B might be mixtures of intermediates and it is difficult to correlate them with a species with specific oxygen-isotope-sensitive bands which are observed at 804,356 , and $785 \mathrm{~cm}^{-1}$ for ${ }^{16} \mathrm{O}_{2}$ in the order of their appearance. The intermediate which is generated in the reaction of mixed-valence enzyme with $\mathrm{O}_{2}$, gives the oxygen-isotope-sensitive bands at 804 and $356 \mathrm{~cm}^{-1}$. The final intermediate in the dioxygen cycle has an $\mathrm{Fe}_{a, 3}{ }^{111}-\mathrm{OH}^{-}$heme with $\mathrm{V}_{\mathrm{Fe}-\mathrm{OH}} \mathrm{RR}$ band at $450 \mathrm{~cm}^{-1}$. This $\mathrm{OH}^{-}$group is exchangeable with bulk water.

In the reaction of oxidized enzyme with $\mathrm{H}_{2} \mathrm{O}_{2}$, the first intermediate, the "607 nm" form, has long been thought to have the peroxo $\mathrm{Fe}_{a 3}-\mathrm{O}-\mathrm{O}-\mathrm{X}$ structure, but $\mathrm{RR}$ experiments demonstrated that it contains an oxoiron heme. The subsequent intermediates give a broad difference peak at $580 \mathrm{~nm}$ and seem to have multiple components. RR spectroscopy can sort out two species within the "580 nm" form. One gives the oxygen-isotope-

Fig. 9. The 607-nm excited steady-state RR spectra in the $800 \mathrm{~cm}^{-1}$ region of the "607 nm" form of $\mathrm{CcO}$ formed in the reaction of the oxidized enzyme with hydrogen peroxide. Hydrogen peroxide used are $\mathrm{H}_{2}{ }^{16} \mathrm{O}_{2}$ (A), $\mathrm{H}_{2}{ }^{88} \mathrm{O}_{2}$ (B), and $\mathrm{H}_{2}{ }^{16} \mathrm{O}^{18} \mathrm{O}(\mathrm{C})$. Spectra $\mathrm{D}$ and $\mathrm{E}$ show difference spectra: spectrum $D=\operatorname{spectrum} A-\operatorname{spectrum} B ; \operatorname{spectrum} E=$ spectrum C - (spectrum A + spectrum B) $/ 2$. The inset (Spectrum D) is the same as spectrum D in the main frame but shows the full frequency range measured. Experimental conditions; cross section of flow cell, $0.6 \times 0.6$ $\mathrm{mm}^{2}$; slit width, $4.2 \mathrm{~cm}^{-1}$; laser $607 \mathrm{~nm}, 100 \mathrm{~mW}$ at the sample; total accumulation time, 78, 78, and $156 \mathrm{~min}$ for spectra A, B and C, respectively, and $160 \mathrm{~min}$ for the resting enzyme; cytochrome $c$ oxidase, $50 \mu \mathrm{M}, \mathrm{pH} 7.45$. (Taken from Ref. 31).

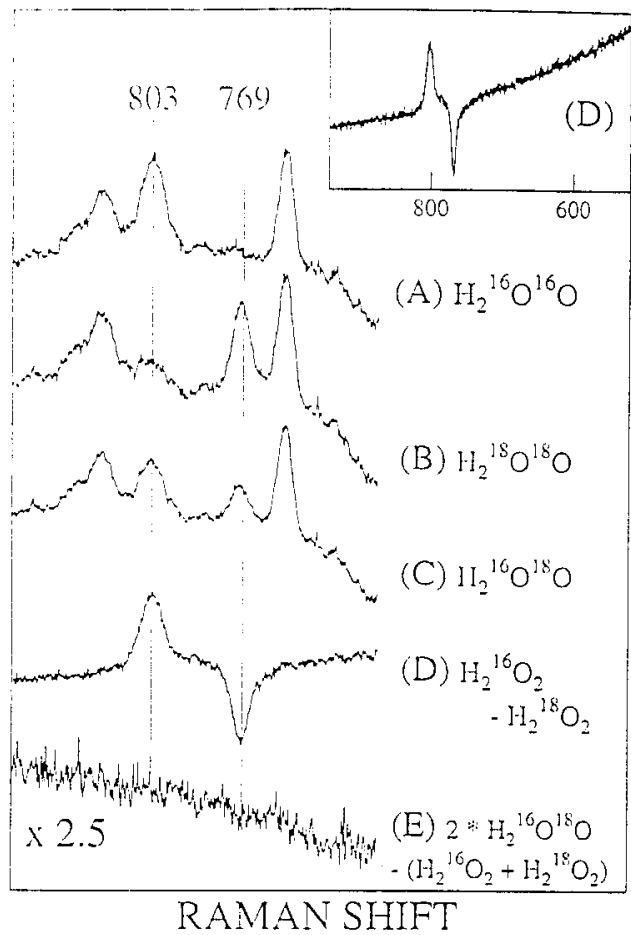


Fig. 10. Reaction mechanism of cytochrome $c$ oxidase, inter-relations of intermediates obtained with different techniques, and the specific oxygen-associated vibrational frequencies $\left({ }^{16} \mathrm{O}_{2}\right.$ derivatives $/{ }^{18} \mathrm{O}_{2}$ derivatives in $\mathrm{cm}^{-1^{2}}$ unit) of individual intermediates. In the dioxygen reaction the fully reduced $\left(4 \mathrm{e}^{-}-\right.$ reduced) and the mixed-valence ( $2 \mathrm{e}^{-}-$ reduced) species are contained. The peroxide reacion gives rise to two absorption forms, but the "580 $\mathrm{nm}$ " form is of multiple species and is further sorted out by vibrational frequencies. The "peroxy" and "ferryl" forms in the reversed reaction are presumably the same as the "607 $\mathrm{nm}^{\prime \prime}$ and $580 \mathrm{~nm}$ " forms of the peroxide reaction, respectively.

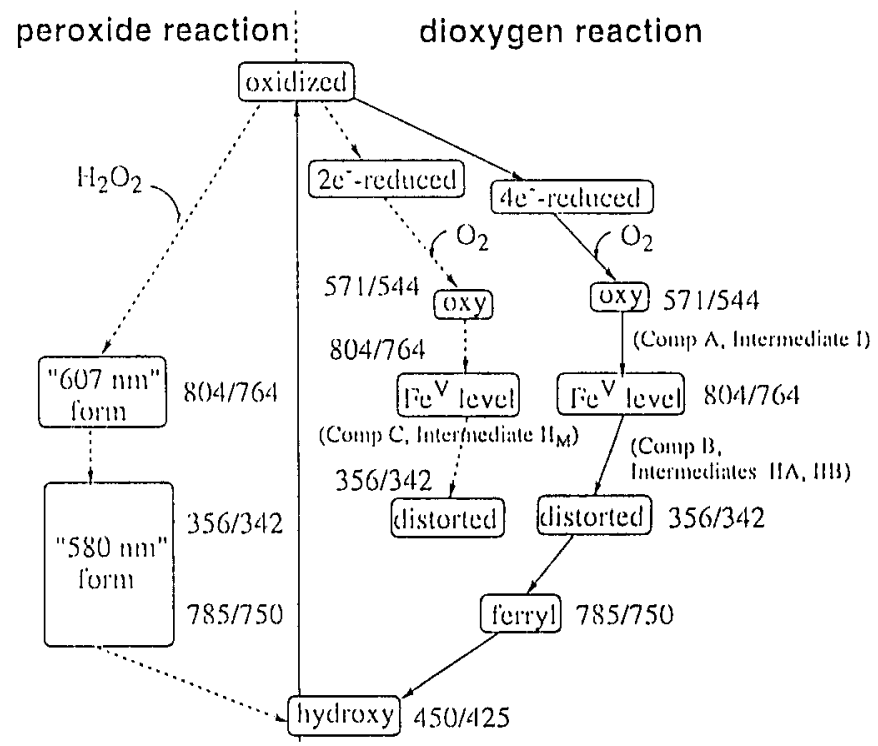

sensitive bands at 356 and $~ 800 \mathrm{~cm}^{-1}$ and the other gives the band at $785 \mathrm{~cm}^{-1}$. The latter is unquestionably assigned to the $\mathrm{Fe}^{\mathrm{IV}}=\mathrm{O}$ stretching mode.

\section{REFERENCES}

1. M.Wikstrom, K.Krab, and M.Saraste.Cytochrome Oxidase; A Synthesis , Academic Press, New York (1981).

2. G. T. Babcock and M. Wikstrom. Nature, 356, 301-309 (1992).

3. M.Wikstrom. Proc. Natl. Acad. Sci. U.S.A. 78, $4051-4055$ (1981).

4. N.Sone and P.C.Hinkle. J. Biol. Chem. 257, 12600-12604 (1982).

5. T.Tsukihara, H.Aoyama, E.Yamashita, T.Tomizaki, H.Yamaguchi, K.Shinzawa-Itoh,R.Nakashima, R.Yaono, and S.Yoshikawa. Science 269, 1069-1074 (1995).

6. Y. Orii Ann. N. Y. Acad. Sci, 550, 105-117 (1988).

7. R. S. Blackmore, C. Greenwood and Q. H. Gibson J. Biol. Chem. 266, 19245-19249 (1991).

8. M. Oliveberg and B. G. Malmstrom. Biochemistry, 31, 3560 (1992).

9. B. Chance, C. Saronio and J. S. Leigh, Jr. J. Biol. Chem., 250, 9226-9237 (1975).

10. G. M. Clore, L. -E. Andreasson, B. Karlsson, R. Aasa, and B. G. Malmstrom.Biochem. J., 185, 139-154 (1980).

11. D. F. Blair, S. N. Witt and S. I. Chan. J. Am. Chem. Soc., 107, 7389-7399 (1985).

12. C. Varotsis, W. H. Woodruff and G. T. Babcock. J. Am. Chem. Soc., 111, 6439; (1989) 112:1297 (1990).

13. C. Varotsis, Y. Zhang, E. H. Appelman and G. T. Babcock. Proc. Natl. Acad. Sci. U.S.A., 90,237 (1993).

14. S. Han, Y. -c. Ching and D. L. Rousseau. Proc. Natl. Acad.Sci. U.S.A., 87, 2491-2495 (1990).

15. S. Han, Y. -c. Ching and D. L. Rousseau. Nature, 348, 89-90 (1990).

16. T. Ogura, S. Takahashi, K. Shinzawa-Itoh, S. Yoshikawa and T. Kitagawa. J. Am. Chem. Soc., 112:5630-5631 (1990),

17. T. Ogura, S. Takahashi, K. Shinzawa-Itoh, S. Yoshikawa and T. Kitagawa. Bull. Chem. Soc. Jpn., 64, 2901-2907 (1991).

18. T. Ogura, S. Takahashi, S. Hirota, K. Shinzawa-Itoh, S. Yoshikawa, E. H. Appelmanand T. Kitagawa. J. Am. Chem. Soc. $115,8527-8536$ (1993).

19. T. Ogura, S. Hirota, D. A. Proshlyakov, K. Shinzawa-Itoh, S. Yoshikawa and T. Kitagawa. J. Am. Chem Soc. 118, 5443-5449 (1996)

20. T. Kitagawa, and T. Ogura. Progr. Inorg. Chem. 45, $431-479$ (1997).

21. T. Kitagawa and T. Ogura Adv. Spectrosc. 21, 139-188 (1993).

22. T. Ogura, and T. Kitagawa. Rev. Sci. Instrum. 59, 1316-1320 (1988).

23. K. Nagai, T. Kitagawa and H. Morimoto. J. Mol. Biol., 136, 271-289 (1980)..

24. S. A. Asher and T. M. Schuster. Biochemistry, 18, 5377-5387 (1979).

25. S. Han, Y. -c. Ching and D. L. Rousseau. J. Am. Chem. Soc., 112, 9445-9450 (1990).

26. C. Varotosis, W. H. Woodruff and G. T. Babcock. J. Biol. Chem., 265, 11131-11136 (1990),

27. S.Hirota, T. Mogi, T. Ogura, T. Hirano, Y.Anraku, and T. Kitagawa. FEBS Lett. 352, 67-70 (1994)

28. T. V. Vygodina and A. A. Konstantinov. Ann. N. Y. Acad. Sci., 550, 124-138 (1988).

29. M. Fabian and G. Palmer. Biochemistry 34, 13802-13810 (1995).

30. D. A. Proshlyakov, T. Ogura, K. Shinzawa-Itoh, S. Yoshikawa, and T. Kitagawa. Biochemistry 35, 76-82 (1996).

31. D. A. Proshlyakov, T. Ogura, K. Shinzawa-Itoh, S. Yoshikawa, E. H. Appelman and T. Kitagawa. J. Biol. Chem., 269, 29385-29388 (1994).

32. D. A. Proshlyakov, T. Ogura, K. Shinzawa-Itoh, S. Yoshikawa and T. Kitagawa. Biochemistry 35, 8580-8586 (1996). 